\title{
Expression and Localization of Gastrin Messenger RNA and Peptide in Spermatogenic Cells
}

\author{
Martin Schalling, * Håkan Persson, " Markku Pelto-Huikko, ${ }^{\star 5}$ Lars Ödum," Peter Ekman," \\ Christer Gottlieb, "* Tomas Hökfelt, " and Jens F. Rehfeld" \\ Departments of ${ }^{*}$ Histology and Neurobiology, ${ }^{\ddagger}$ Medical Chemistry, and Laboratory of Molecular Neurobiology, Karolinska Institute, \\ and 'Urology, and ** Obstetrics and Gynecology, Karolinska Hospital, S-104 01 Stockholm, Sweden; $\$$ Department of Biomedical \\ Sciences, University of Tampere, SF-33101 Tampere, Finland; and "University Department of Clinical Chemistry, \\ Rigshospitalet, DK-2100 Copenhagen, Denmark
}

\begin{abstract}
In previous studies we have shown that the gene encoding cholecystokinin (CCK) is expressed in spermatogenic cells of several mammalian species. In the present study we show that a gene homologous to the CCK-related hormone, gastrin, is expressed in the human testis. The mRNA hybridizing to a human gastrin cDNA probe in the human testis was of the same size $(0.7 \mathrm{~kb})$ as gastrin $\mathrm{mRNA}$ in the human antrum. By in situ hybridization the gastrinlike mRNA was localized to seminiferous tubules. Immunocytochemical staining of human testis revealed gastrinlike peptides in the seminiferous tubules primarily at a position corresponding to spermatids and spermatozoa. In ejaculated spermatozoa gastrinlike immunoreactivity was localized to the acrosome. Acrosomal localization could also be shown in spermatids with electron microscopy. Extracts of the human testis contained significant amounts of progastrin, but no bioactive amidated gastrins. In contrast, ejaculated sperm contained mature carboxyamidated gastrin 34 and gastrin 17. The concentration of gastrin in ejaculated human spermatozoa varied considerably between individuals. We suggest that amidated gastrin (in humans) and CCK (in other mammals) are released during the acrosome reaction and that they may be important for fertilization. (J. Clin. Invest. 1990. 86:660-669.) Key words: activation • cholecystokinin • fertilization • neuropeptide $\bullet$ sperm
\end{abstract}

\section{Introduction}

The gastrointestinal hormones gastrin and cholecystokinin $(\mathrm{CCK})^{1}$ are homologous. They share an identical carboxyl-terminus Gly-Trp-Met-Asp-Phe- $\mathrm{NH}_{2}$, which contains the active site of both hormones $(1,2)$. The active site homology explains the overlapping spectra of activity and suggests that gastrin and CCK are derived from a common ancestor (3). This suggestion is supported by analysis of mammalian gastrin and CCK preprohormone structures (4-9) and by the recent detection of an invertebrate hybrid of mammalian gastrin and CCK (10).

Address reprint requests to Dr. Rehfeld, University Department of Clinical Chemistry, Rigshospitalet, DK-2100 Copenhagen, Denmark. 1990

Received for publication 14 March 1990 and in revised form 7 May

1. Abbreviations used in this paper: CCK, cholecystokinin; proCCK, procholecystokinin.

J. Clin. Invest.

(c) The American Society for Clinical Investigation, Inc. $0021-9738 / 90 / 08 / 660 / 10 \quad \$ 2.00$

Volume 86, August 1990, 660-669
Gastrin and CCK peptides are synthesized throughout the body in different cell types (for review, see Rehfeld [11]). The gastrin gene is expressed mainly in the antroduodenal $\mathbf{G}$ cells, and to a minor extent in the neonatal pancreas (12), vagal neurons (13), pituitary cells (14), and bronchial mucosal cells (15). In addition to I cells of the small intestine, the CCK gene is expressed in multiple central (16-19) and peripheral neurons (20), in pituitary corticotrophs (21) and, as recently reported, in spermatogenic cells of several mammalian species $(22,23)$.

The CCK peptides in spermatogenic cells are accumulated in the acrosome (22-24). CCK receptors have been detected on frog oocytes (25), and we have suggested that accumulated CCK peptides in the acrosome of spermatids and spermatozoa may be released during the acrosome reaction and participate in the fertilization process. Consequently, it became pertinent to examine human spermatogenic cells also for expression of the CCK gene. As shown here, human spermatogenic cells express instead an mRNA hybridizing to a human gastrin cDNA clone of the same size as gastrin mRNA in the antrum. In agreement with this, progastrin was found in the human testis, and bioactive $\alpha$-amidated gastrin was detected in ejaculated human sperm cells. Thus, human spermatogenic cells appear to express the gene encoding the CCK-related hormone gastrin, rather than CCK expressed in spermatogenic cells of other mammals $(22,23)$.

\section{Methods}

RNA blot analysis. Total RNA was prepared from the indicated tissues by homogenization in $4 \mathrm{M}$ guanidine isothiocyanate, $0.1 \mathrm{M} \beta$-mercaptoethanol, $0.025 \mathrm{M}$ sodium citrate ( $\mathrm{pH} 7.0$ ) followed by centrifugation through a cushion of $\mathrm{CsCl}$ (26). Polyadenylated RNA was purified by oligo (dT)-cellulose chromatography (27), electrophoresed in $1 \%$ agarose gels containing $0.7 \%$ formaldehyde, and transferred to nitrocellulose filters, as previously described (26). The filters were then hybridized to a 600-bp Alu 1 fragment including the second exon of the human CCK gene (8) or a 300-bp human gastrin cDNA insert (5) labeled with $\left[\alpha-{ }^{32} \mathrm{P}\right] \mathrm{dCTP}$ by nick-translation to a specific activity of $\sim 5 \times 10^{8} \mathrm{cpm} / \mu \mathrm{g}$. Filters containing RNA prepared from monkey and human tissues were first washed at reduced stringency $(0.2 \times$ SSC $0.1 \% \mathrm{SDS}, 48^{\circ} \mathrm{C} ; 1 \times \mathrm{SSC}$ is $150 \mathrm{mM} \mathrm{NaCl}, 15 \mathrm{mM}$ sodium citrate, $\mathrm{pH}$ 7.0) and later, after an initial exposure to $x$-ray film, at high stringency $\left(0.1 \times \mathrm{SSC}, 0.1 \% \mathrm{SDS}, 54^{\circ} \mathrm{C}\right)$. The filters were exposed to XAR -5 films (Eastman Kodak Co., Rochester, NY) after both washes using intensifying screens (DuPont Co., Wilmington, DE).

In situ hybridization. Testes from human and grey monkey were collected with $<1 \mathrm{~h}$ of postoperative delay, immersed in $4 \%$ paraformaldehyde in phosphate buffer containing $0.3 \%$ picric acid (28) for 2-3 $\mathrm{h}$, and transferred to $10 \%$ sucrose in $0.1 \mathrm{M}$ phosphate buffer and left overnight. Sections were cut in a cryostat (Dittes, Heidelberg, 
FRG) and thawed onto glass slides dipped in poly-L-lysine (100 mg/ liter). The sections were then hybridized to three oligonucleotides complementary to, respectively, rat and human CCK, human tyrosine hydroxylase, and human gastrin mRNA, as previously described (29), with the exception that sections were hybridized directly after thawing without any pretreatment or immersion in fixative. The oligonucleotides were synthesized on a DNA synthesizer (model 381A, Applied Biosystems, Inc., Foster City, CA), purified with oligonucleotide purification cartridges (Applied Biosystems, Inc.) and labeled at their 3'-end using terminal deoxynucleotidyl transferase (International Biotec Inc., New Haven, CT) and $\left[\alpha^{35} \mathrm{~S}\right] \mathrm{dATP}$ (New England Nuclear, Boston, MA) to a specific activity of $7-10 \times 10^{8} \mathrm{cpm} / \mu \mathrm{g}$. The oligonucleotides were complementary to nucleotides 265-308 of human CCK mRNA (9), 151-211 of human gastrin (5), and 1-48 of human tyrosine hydroxylase (30).

After hybridization, sections were washed at $55^{\circ} \mathrm{C}$ in $1 \times \mathrm{SSC}$ for 60 min with four changes, transferred through distilled water and $60 \%$ and $95 \%$ ethanol, air-dried, and exposed to $\mathrm{x}$-ray film for $4 \mathrm{~d}$ (antrum) and $34 \mathrm{~d}$ (testis). Subsequently, NTB2 (Kodak) nuclear track emulsion was applied, and finally the sections were stained with cresyl violet. The x-ray film was developed for $2 \mathrm{~min}$ in LX 24 (Kodak) and fixed in L4 (Kodak) for $15 \mathrm{~min}$. The nuclear track emulsion was developed in D19 (Kodak) for 2.5 min and fixed in G333 (Agfa Gefvert, Leverkusen, FRG) for $4 \mathrm{~min}$. The autoradiograms were analyzed in a Mikrophot-FX microscope (Nikon Corp., Tokyo) using dark field illumination.

Measurement of progastrin, proCCK, and their products. Human testes were sampled $<1 \mathrm{~h}$ postoperatively and frozen in liquid nitrogen. The material was taken from patients undergoing surgery for prostate cancer except one case (27-yr-old male), where surgery was performed because of a testicular tumor. Testis and epididymis from gray monkeys were dissected and immediately frozen on dry ice. The sperm was obtained from voluntary donors and frozen immediately. While frozen, the tissue was immersed in boiling water for $20 \mathrm{~min}$, homogenized, and centrifuged at $10,000 \mathrm{~g}$ for $30 \mathrm{~min}$. The supernatant (neutral water extract) was stored at $-20^{\circ} \mathrm{C}$. The pellet was reextracted in $0.5 \mathrm{M}$ acetic acid, rehomogenized, and centrifuged and the supernatant (the acid extract) was stored at $-20^{\circ} \mathrm{C}$. The extracts were assayed with sequence-specific $C C K$ and gastrin radioimmunoassays before and after incubation with trypsin and carboxypeptidase $B$ as previously described (31). Neutral water extracts were applied, separately or together, to Sephadex G-50 superfine columns (Pharmacia, Uppsala, Sweden) before and after trypsin and carboxypeptidase B treatment. The columns were eluted with $0.02 \mathrm{M}$ barbital buffer (pH 8.4) and calibrated with extracts of jejunal mucosa and cerebral cortex, with sulfated and nonsulfated CCK-8, glycine-extended CCK-8, and CCK-12 (CRB, Cambridge, UK), with carboxy-amidated CCK-33, gastrin 34 and gastrin 17. Void and total volumes of the columns were determined with ${ }^{125} \mathrm{I}$-labeled albumin and ${ }^{22} \mathrm{NaCl}$.

Immunohistochemistry. Tissue treatment was as described above for in situ hybridization except that the tissue sections (14 $\mu \mathrm{m}$ thick) were thawed onto gelatin-chromalum-coated glass slides, after which they were processed for indirect immunofluorescence histochemistry (see Coons [32]). To stain ejaculated spermatozoa a smear preparation was fixed with the "double $\mathrm{pH}$ method" of Berod et al. (33) as modified by Pelto-Huikko et al. (24). The smear preparations were first fixed with $4 \%$ paraformaldehyde at $\mathrm{pH} 6.5$ for 5 min followed by the same fixative at pH 11 for $15 \mathrm{~min}$. A rabbit polyclonal antiserum directed towards the common carboxyl-terminal sequence of CCK-8 and gastrin $(18,34)$ and mouse monoclonal antibodies directed against the common carboxyl-terminal sequence of CCK and gastrin (J. Walsh, unpublished method; see reference 19) were used, followed by fluorescein isothiocyanate (FITC)-conjugated goat anti-rabbit antibodies (Boehringer Mannheim Scandinavia, Stockholm, Sweden) or FITCconjugated sheep anti-mouse antibodies (Amersham, Amersham, UK). As a control the sections were incubated with antiserum preadsorbed with $1 \mu \mathrm{M}$ synthetic CCK-8 peptide (Peninsula Laboratories, Inc., Belmont, CA) for $24 \mathrm{~h}$ at $4^{\circ} \mathrm{C}$. After mounting in phosphate-buffered glycerol containing para-phenylenediamine $(35,36)$, the slides were examined in a Mikrophot-FX microscope equipped for epifluorescence and with appropriate filter combinations.

Immunoelectron microscopy. Human testes were sliced and immersion fixed in a mixture of paraformaldehyde (4\%) and glutaraldehyde $(0.2 \%)$ in $0.1 \mathrm{M}$ phosphate buffer $(\mathrm{pH} 7.3)$ for $6 \mathrm{~h}$. The tissues were cryoprotected with $30 \%$ sucrose over night, and $50-\mu \mathrm{m}$ frozen sections were cut. The sections were stained free floating using the pre-embedding modification (37) of the peroxidase-antiperoxidase method (38). Endogenous peroxidase activity was blocked by incubating the sections in $0.5 \% \mathrm{H}_{2} \mathrm{O}_{2}$ in methanol for $30 \mathrm{~min}$. To increase the antibody penetration $0.2 \%$ Triton $X-100$ was applied for $5 \mathrm{~min}$. Nonspecific binding of the antisera was blocked by pretreating the sections for $30 \mathrm{~min}$ with $10 \%$ normal rabbit serum. The sections were incubated for 10-16 $\mathrm{h}$ with the mouse monoclonal CCK antibodies (see above) diluted 1:2,000. After incubation with appropriate secondary antibodies peroxidase activity was visualized with a solution of $0.03 \%$ diaminobenzidine and $0.004 \% \mathrm{H}_{2} \mathrm{O}_{2}$ in PBS. The sections were postfixed with $2 \%$ aqueous $\mathrm{OsO}_{4}$ for 60 min and en bloc stained with $1 \%$ uranyl acetate for $60 \mathrm{~min}$. Sections were dehydrated through graded ethanol and embedded in agar 100 resin. Semithin sections ( $10 \mu \mathrm{m}$ thick) were cut from blocks and attached to glass slides by warming. The sections were inspected in a light microscope, and a capsule filled with agar 100 was inverted on the sections showing immunostaining. After polymerization the capsule was detached. Ultrathin sections were cut on an OMU-3 ultramicrotome (Reichert, Vienna, Austria) and collected on

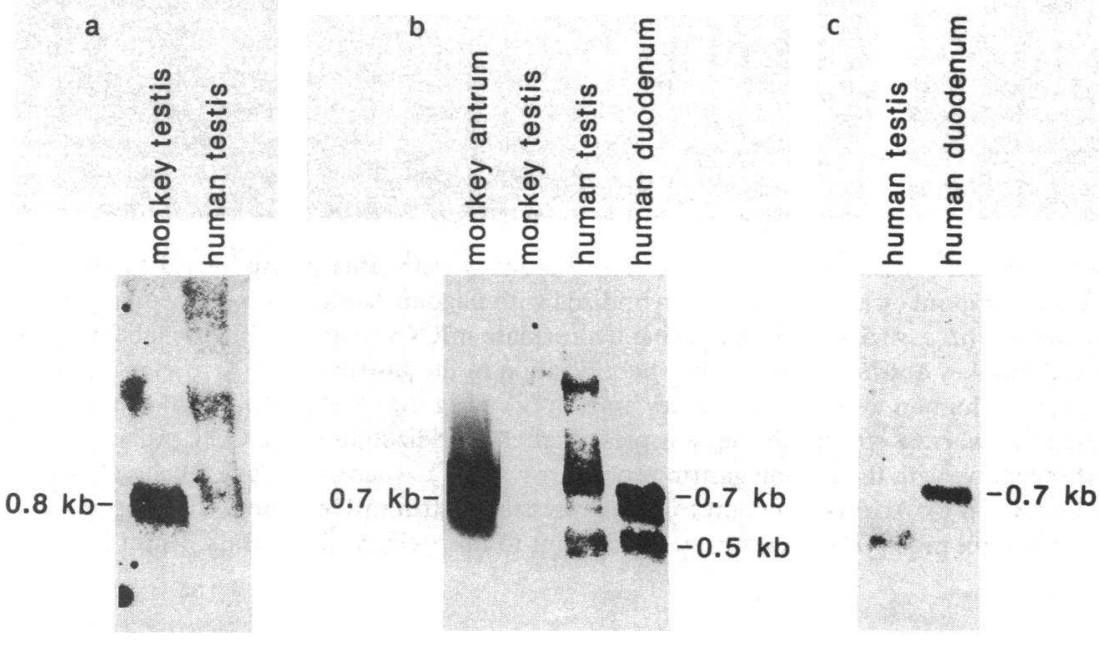

Figure 1. Expression of gastrinlike mRNA in monkey and human testis. Polyadenylated RNA was prepared from the indicated tissues, and 20 $\mu \mathrm{g}$ from each sample was electrophoresed in a formaldehyde-containing agarose gel blotted onto nitrocellulose and hybridized to a human CCK probe ( $a$ ) and a human gastrin probe ( $b$ and $c$ ). The filters in $a$ and $b$ were washed at reduced stringency $\left(0.2 \times \mathrm{SSC}, 0.1 \% \mathrm{SDS}, 48^{\circ} \mathrm{C}\right)$, whereas the filter shown in $c$ was washed at high stringency $\left(0.1 \times \mathrm{SSC}, 0.1 \%\right.$ SDS $\left.54^{\circ} \mathrm{C}\right)$. After washing the filters were exposed to $\mathrm{x}$-ray film using a DuPont intensifying screen. 

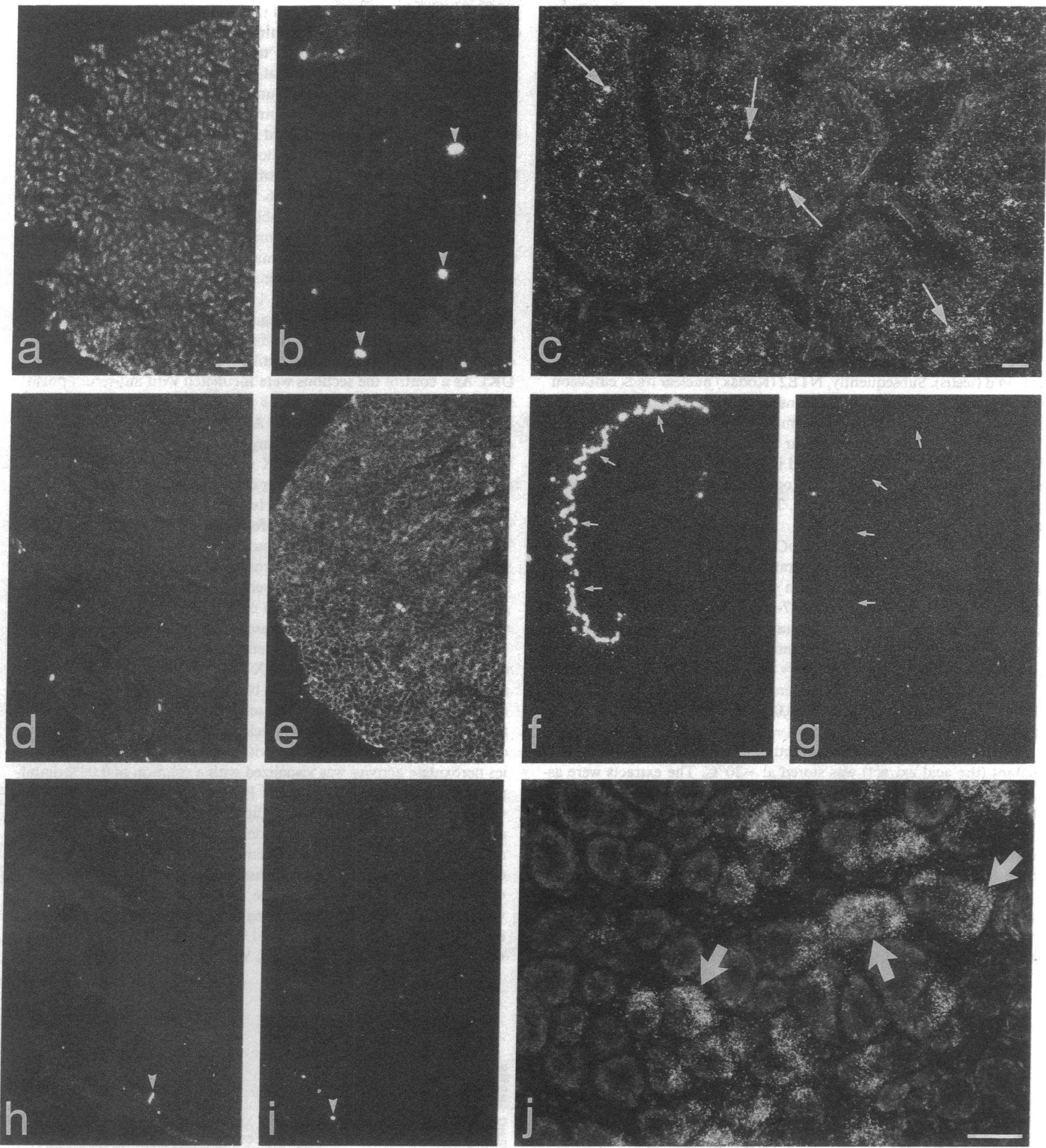

Figure 2. $(a, b, d-i)$ Film and ( $c$ and $j)$ emulsion autoradiographs of sections through human and monkey testes after in situ hybridization. Sections of human $(a, c, d, h)$ and grey monkey $(b, e, i)$ testis and monkey antrum $(f, g, j)$ hybridized with oligonucleotides complementary to human gastrin mRNA $(a-c, f, j)$, rat and human CCK mRNA $(d, e, g)$ and human tyrosine hydroxylase mRNA $(h$ and $i)$. Intense labeling was seen overlying human seminiferous tubules $(a$ and $c)$ and monkey antrum $(f$ and $j)$ after hybridization to the gastrin probe. Arrows in $c$ point to structures with high activity. No labeling can be seen in the human testis $(d)$ or monkey antrum $(g)$ using the CCK probe. Monkey testis hybridized with the gastrin probe shows little or no labeling $(b)$, whereas strong labeling was present after hybridization to the CCK probe $(e)$. Note band of labeled cells in monkey antrum after hybridization with the human gastrin probe (arrows in $f$ ), whereas no such labeling is seen in the corresponding place with a human CCK probe (arrows in $g$ ). Arrows in $j$ point to cells expressing gastrin mRNA (emulsion-dipped section). No labeling is seen using tyrosine hydroxylase as a control probe ( $h$ and $i)$. Arrow heads point to unspecific activity. Bars, $1 \mathrm{~mm}(a, b$, $d-i)$ or $50 \mu \mathrm{m}(c$ and $j)$. 
Table I. Concentrations (Median and Range) of Progastrins, Glycine-extended Intermediate Precursors and Mature Carboxyamidated Gastrins in Human Testes and Spermatozoes

\begin{tabular}{clll}
\hline Tissue & Progastrins & $\begin{array}{c}\text { Glycine-extended } \\
\text { gastrins }\end{array}$ & $\begin{array}{c}\text { Carboxyamidated } \\
\text { gastrins }\end{array}$ \\
\hline & & pmol/g tissue, wet wt & \\
& & $1.0(0.8-1.2)$ & 0 \\
$\begin{array}{c}\text { Testicular tissue }(n=5)^{*} \\
\begin{array}{c}\text { Ejaculated spermatozoes } \\
(n=6)^{*}\end{array}\end{array}$ & $5.0(4.2-5.2)$ & $0(0-2.9)$ & $0.8(0-3.9)$ \\
\hline
\end{tabular}

* Number of samples (from individual males).

100-mesh copper grids, contrasted with uranyl acetate and lead citrate and examined in an electron microscope (model $1200 \mathrm{EX}$, JEOL, Tokyo, Japan).

\section{Results}

Detection of a gastrinlike mRNA in the human testis. Polyadenylated RNA was prepared from human testis and duodenum, as well as from monkey antrum and testis. In agreement with a previous study (23), high levels of an 800-nucleotide-long CCK mRNA were found in monkey testis (Fig. $1 a$ ). In contrast, the CCK probe only hybridized weakly to a $0.8-\mathrm{kb}$ transcript in the human testis.

The human gastrin cDNA probe hybridized strongly to a 700-nucleotide-long gastrin mRNA in monkey antrum, but showed no hybridization to any RNA transcript in the monkey testis (Fig. $1 b$ ). In the human testis, the gastrin cDNA probe hybridized to a $0.7-\mathrm{kb}$ transcript under reduced stringency $\left(0.2 \times \mathrm{SSC}, 48^{\circ} \mathrm{C}\right)$ as well as to a smaller, $\sim 0.5$-kb-long transcript (Fig. $1 b$ ). The same-size transcripts were also seen in the human duodenum using the gastrin cDNA probe. However, after high-stringency washing of the filter $\left(0.1 \times \mathrm{SSC}, 54^{\circ} \mathrm{C}\right)$, the levels of the transcripts in the human testis that hybridized to the gastrin cDNA probe were greatly reduced, whereas the $0.7-\mathrm{kb}$ transcript in the human duodenum was still present at a level comparable to that seen under reduced stringency (Fig. 1 c). The same results were obtained using RNA preparations from five different individuals ranging in age from 27 to 68 yr old.

In situ hybridization of monkey and human testis. The human testis showed strong labeling over the seminiferous tubules after hybridization to a 61-mer oligonucleotide complementary to human gastrin mRNA (Fig. $2 a$ and $c$ ), but only background labeling with a 44-mer oligonucleotide probe specific for human CCK mRNA (Fig. $2 b$ ). The gastrin probe labeled G-cells of monkey antrum strongly (Fig. $2, f$ and $j$ ), but this was not seen with the CCK probe (Fig. $2 \mathrm{~g}$ ). In the monkey testis, dense labeling with the CCK probe was found overlying the basal part of the seminiferous tubules, where spermatogonia, spermatides, and Sertoli cells are found (Fig. $2 e$ ). In contrast, the gastrin probe did not show any labeling in the monkey testis (Fig. $2 d$ ). A control probe, complementary to human tyrosine hydroxylase, with similar specific activity, length, and GC content, which hybridizes strongly to human adrenal medulla tissue (data not shown), did not label either human or monkey testis (Fig. 2, $h$ and $i$ ).

Identification of progastrin, proCCK, and their products in human testes. Using radioimmunoassays specific for different sequences of progastrin and proCCK, progastrin peptides were detected in the human testis, but no $\alpha$-carboxyamidated gastrin peptides were measured (Table I). However, extracts of ejaculated human spermatozoa contained $\alpha$-carboxyamidated gastrin-34 and gastrin-17 peptides in addition to progastrin peptides. ProCCK was measured in extracts of monkey testis and epididymis. Only small amounts of bioactive, mature peptides were found in the extracts. The concentrations of fully processed $\alpha$-carboxyamidated CCK- 8 in monkey testis and epididymis were $\sim 100$ times lower compared with the duodenal mucosa (Table II). Characterization of the various CCK and gastrin peptides present in monkey and human testes confirmed that the vast majority of these peptides were present in their precursor form (Fig. 3). However, a similar analysis in ejaculated human spermatozoa revealed that the gastrin peptides in these samples corresponded to the bioactive $\alpha$-carboxyamidated gastrin 34 and gastrin 17 (Fig. 4).

Immunohistochemical localization of gastrin and CCK peptides. An antiserum directed to the carboxyl-terminal part common to CCK and gastrin was used in the present study. Thus, our antiserum cannot distinguish between these two peptides. However, since both hybridization and biochemical studies indicate presence of a gastrinlike peptide, we will throughout this paper use the term gastrinlike immunoreactivity.

Sections from adult human testis revealed small gastrinimmunoreactive structures in the seminiferous tubules predominantly at a position corresponding to the localization of spermatids and spermatozoa (Fig. 5, $a$ and $c$ ). The fluorescent structures were often crest-shaped and sometimes rounded. Different seminiferous tubule profiles showed varying numbers of positive structures with different intensities, and some tubules profiles seemed to lack staining. Both Leydig cells and cells in the peripheral parts of the seminiferous tubules were nonimmunoreactive. In a smear of ejaculated spermatozoa, intensely stained structures were present at the anterior pole of the head of the spermatozoa (cf. Fig. 5, $b$ and $d$ ). The immunoreactive structures had a semicircular and sometimes crestshaped appearance and were present in a large proportion of spermatozoa, although unlabeled and more weakly labeled structures could be clearly distinguished (Fig. 5, $d$ and $f$ ). Comparing the same smears using phase-contrast microscopy (Fig. $5 f$ ), further defined the exact localization of the immunoreactivity within spermatozoa (Fig. $5 d$ ). Preadsorption of the antibodies with synthetic CCK-8 peptide abolished the immunoreactivity seen in the human testis (Fig. $5 e$ ).

Table II. Concentrations (Median and Range) of Procholecystokinin, Glycine-extended Intermediate Precursors and Mature Carboxyamidated CCK in Monkey Testes and Epididymis

\begin{tabular}{cccc}
\hline Tissue & Procholecystokinins & $\begin{array}{c}\text { Glycine-extended } \\
\text { cholecystokinins }\end{array}$ & $\begin{array}{c}\text { Carboxyamidated } \\
\text { cholecystokinins }\end{array}$ \\
\hline \multicolumn{4}{c}{ pmol/g tissue, wet wt } \\
$\begin{array}{c}\text { Testicular tissue } \\
(n=2)^{*}\end{array}$ & $22(21-23)$ & $1.2(1.1-1.3)$ & $0.4(0.3-0.4)$ \\
$\begin{array}{c}\text { Epididymis } \\
(n=2)^{*}\end{array}$ & $7.9(6.5-9.3)$ & $0.7(0.4-1.0)$ & $0.7(0.7-0.7)$ \\
\hline
\end{tabular}

* Number of samples. 

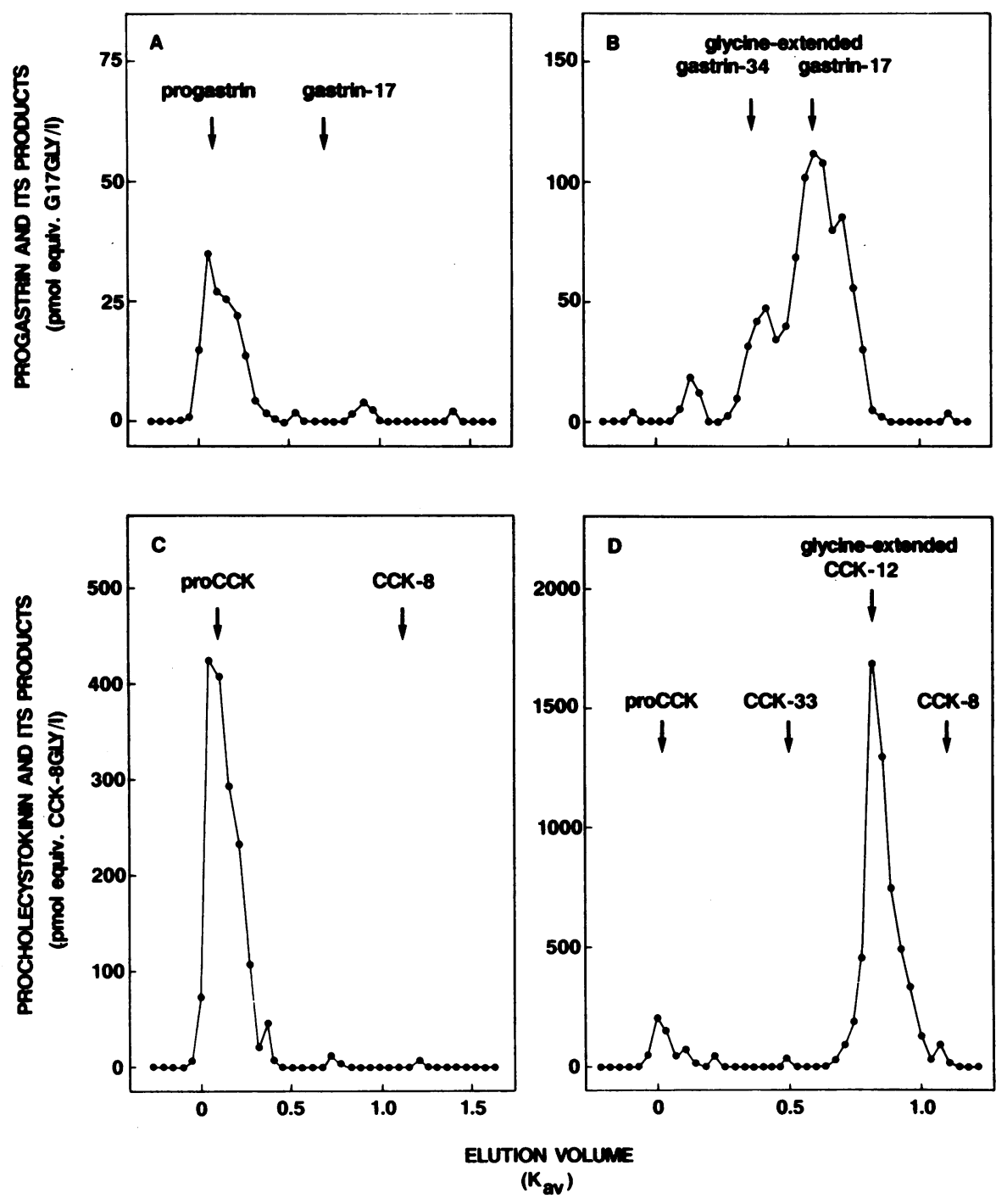

Figure 3. Sephadex G50 gel chromatography of extracts from testicular tissue. $(A)$ Elution profile of extract of undigested progastrin from human testes. $(B)$ Elution profile of extract from human testes after trypsin-carboxypeptidase $B$ digestion of the progastrin before column application. $(C)$ Elution profile of extract of undigested procholecystokinin (proCCK) from monkey testis. $(D)$ Elution profile of extract from monkey testes after trypsin-carboxypeptidase $B$ digestion of the proCCK before column application. For details of the analytical procedure, see Methods.

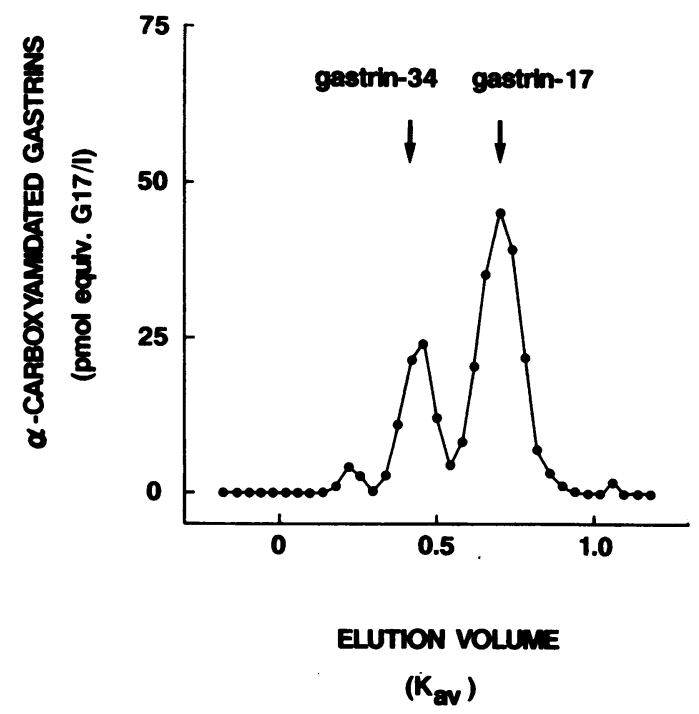

Figure 4. Sephadex G50 gel chromatography of extract of ejaculated human spermatozoa. The elution profile represents undigested gastrin. For details of the analytical and chromatographic procedures, see Methods.
Immunoelectron microscopic localization of the gastrinlike peptides in human spermatogenic cells. At the electron microscopic level the gastrinlike immunoreactivity in the human testis was found in the acrosomal cap of spermatids (Fig. 6, $a$ and $b$ ). No clear staining was observed in the cytoplasm of spermatids. Both Sertoli cells and interstitial Leydig cells were nonimmunoreactive. After preadsorption of the antiserum with synthetic CCK-8 peptide, no labeling of acrosomal vesicles could be seen.

\section{Discussion}

The present study shows that progastrin peptides are present in the human testis and that $\alpha$-carboxyamidated gastrin-17 and gastrin-34 peptides are present in ejaculated human sperms. In agreement with this, a 0.7-kb mRNA species with the same size as gastrin mRNA in the antrum and duodenum was detected in human testis by Northern blot analysis using a human gastrin cDNA probe. Furthermore, a 61-mer oligonucleotide specific for human gastrin mRNA showed labeling over the seminiferous tubules in the human testis using in situ hybridization. In the monkey testis, previously shown to ex- 

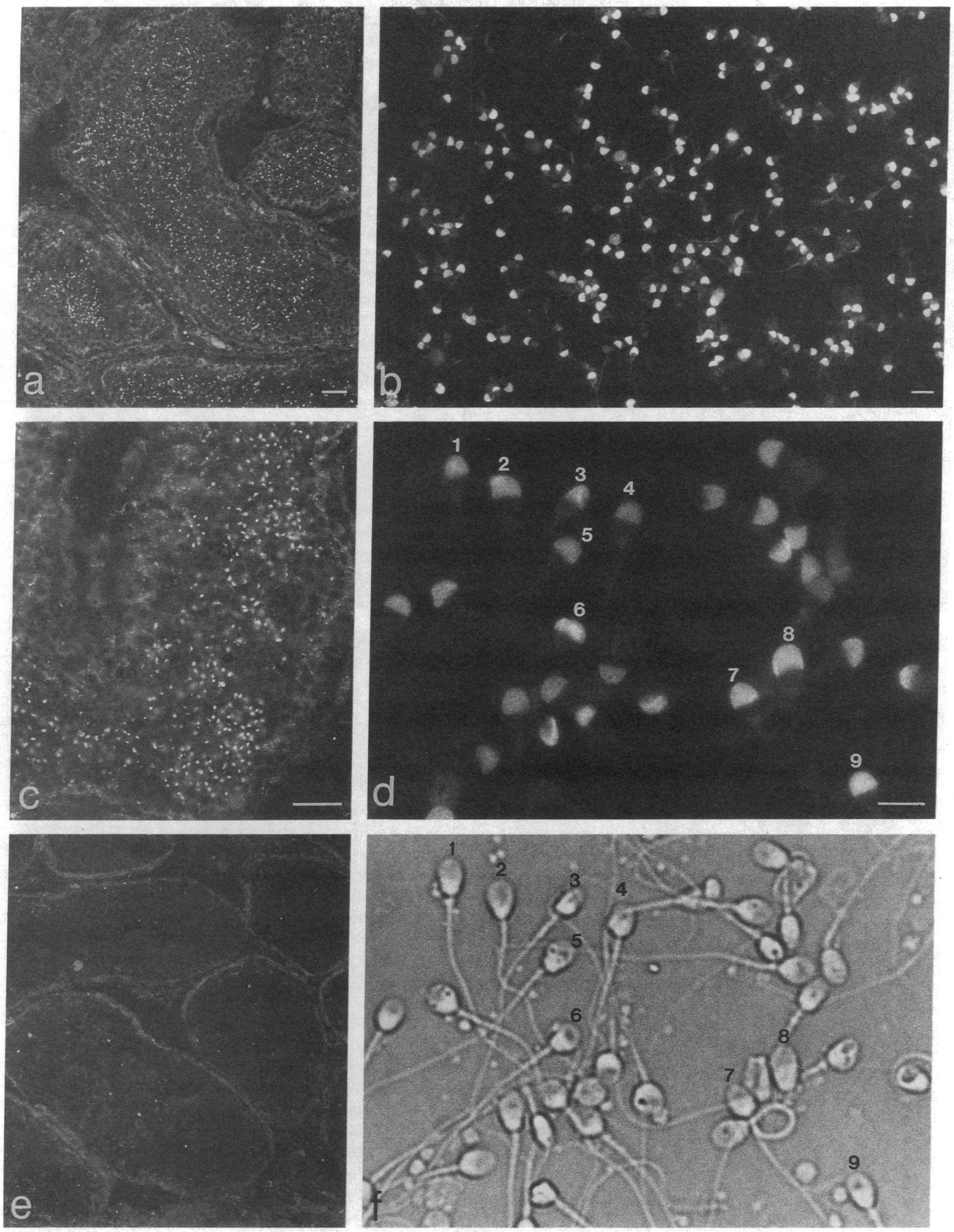

Figure 5. 

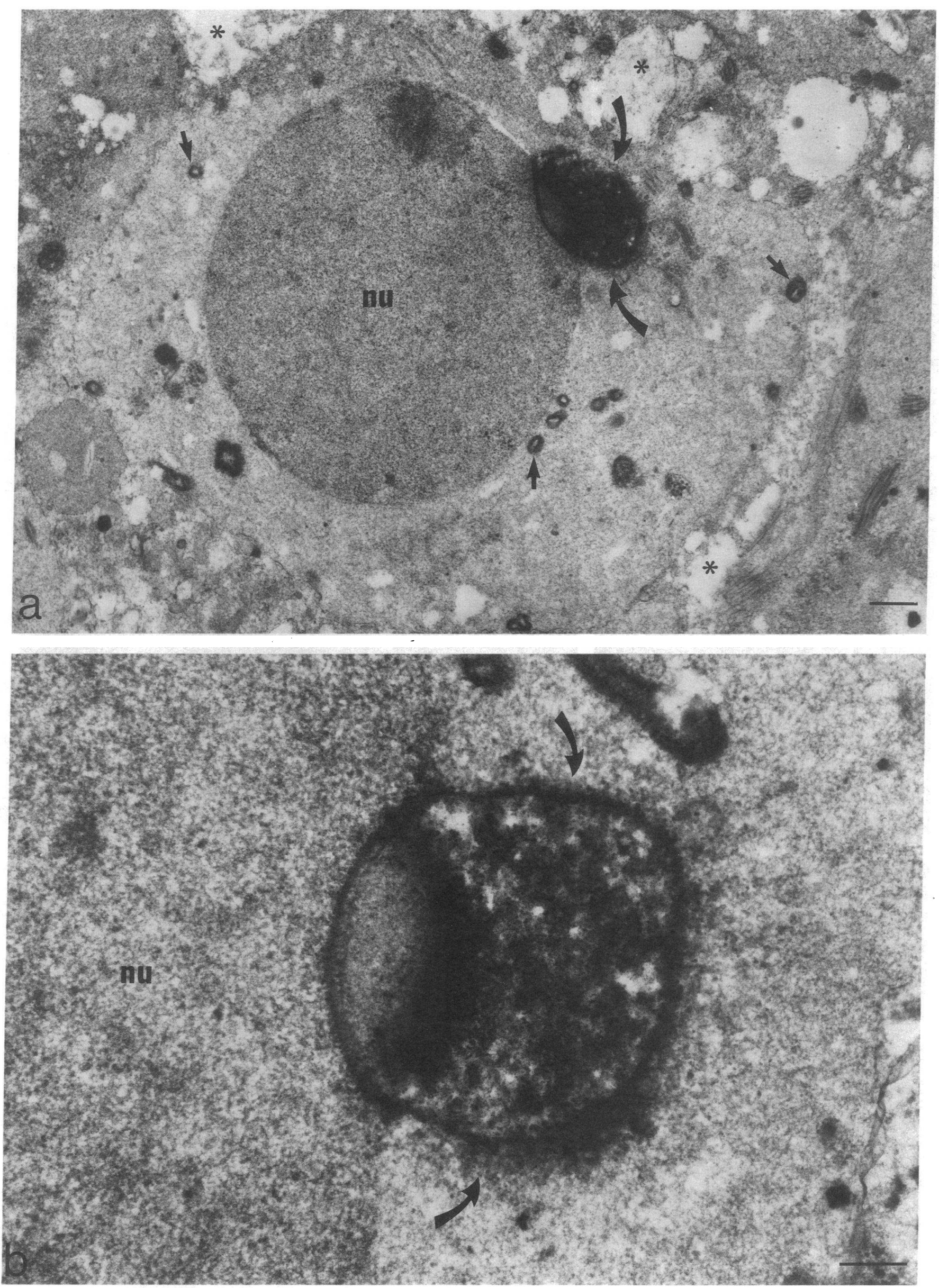

Figure 6. 
Figure 5. Immunohistochemical staining of human testis and ejaculated sperm. $(a-e)$ Immunofluorescence and $(f)$ phase-contrast micrographs of human testis $(a, c, e)$ and smear of human sperm $(b, d, f)$ after incubation with antiserum to the carboxyl-terminal portion of gastrin/CCK $(a-d)$ or CCK antiserum preabsorbed with CCK octapeptide $(e)$. $(f)$ Same section as in $d$ but viewed in the phase-contrast microscope. Numerous dotlike structures can be seen mainly located in the central portion of the seminiferous tubules $(a$ and $c)$. After incubation with preabsorbed antiserum, no such staining can be observed $(e)$. In a smear of ejaculated sperms, gastrinlike immunoreactivity can be seen in most sperm heads, distinctly located to the anterior pole of the head $(b$ and $d)$. Comparison with the phase-contrast image $(f)$ provides information on the exact localization of gastrinlike immunoreactivity. Some of the sperm cells have been numbered 1-9 for comparison. Bars, $50 \mu \mathrm{m}(a, c$, $e)$ and $5 \mu \mathrm{m}(b, d, f)$.

Figure 6. Electron micrograph of human spermatid. Electron micrographs of human spermatid $(a$ and $b)$ after incubation with gastrin/CCK carboxyl-terminal antiserum and processing for the peroxidase antiperoxidase technique. (a) Immunoreactivity is localized in the acrosome (curved arrows). Mitochondria and multivesicular bodies (small arrows) in the cytoplasm exhibit nonspecific osmiofilia. Some fixation processing artefacts are seen (stars). ( $n u$ ) Nucleus. Bar, $1 \mu \mathrm{m}$. (b) Higher magnification of a labeled acrosome. Immunoreaction is seen in the acrosomal vesicle and in the acrosomal granule. $(n u)$ Nucleus. Bar, $0.2 \mu \mathrm{m}$.

press CCK mRNA (23), the human gastrin CDNA probe did not hybridize to any RNA transcript, whereas the same probe revealed high levels of a $0.7-\mathrm{kb}$ gastrin mRNA in the monkey antrum. Similarly, in situ hybridization experiments revealed no labeling over sections from monkey testis using the human gastrin-specific oligonucleotide, whereas an oligonucleotide specific for human CCK mRNA showed labeling over the peripheral parts of the seminiferous tubules in this species. Hence, it appears that the gastrin gene is expressed in human spermatogenic cells, whereas in monkey, as well as in rat, mouse, guinea pig and pig spermatogenic cells, the gene encoding the gastrin related peptide CCK is expressed (23).

To facilitate the possible detection of gastrin mRNA in the testis of other species than the human (monkey, mouse, rat, guinea pig, and pig) all RNA blots were initially examined after washing at reduced stringency $\left(0.2 \times \mathrm{SSC}, 48^{\circ} \mathrm{C}\right)$. At this stringency a rat gastrin cDNA clone with $73 \%$ nucleotide sequence homology to human gastrin cDNA hybridizes to gastrin mRNA from human antrum (9). In spite of this, the 0.7$\mathrm{kb}$ mRNA that hybridized to the human gastrin cDNA probe was only detected in human testis, suggesting that the gastrin gene is not expressed in the testis of all other species analyzed. Surprisingly, however, the $0.7-\mathrm{kb}$ gastrin mRNA in human testis was barely detected, when the filters had been washed at high stringency $\left(0.1 \times \mathrm{SSC}, 54^{\circ} \mathrm{C}\right)$. This suggests, in spite of the finding of gastrin peptides in human testis and sperms, that the 0.7-kb RNA transcript seen in the human testis does not correspond to authentic gastrin mRNA. Instead this transcript may represent a novel mRNA with relatively high sequence homology to human gastrin mRNA. This interesting possibility should be clarified by the isolation and characterization of a cDNA clone encoding the gastrinlike mRNA detected in human testis.

As observed in the rat testis and epididymis (23), the majority of the CCK peptides in the monkey testis and epididymis represented proCCK peptides. In the epididymis, processed glycine-extended and carboxyamidated CCK peptides represented a larger proportion of the detected CCK peptides than in the testis (23). Also, all gastrin peptides detected in the human testis were in the precursor form. However, in ejaculated human sperm cells, the majority of the gastrin peptides represented fully processed gastrin- 17 and gastrin- 34 peptides corresponding to the bioactive forms seen in the antral mucosa. These data suggest that the CCK and gastrin peptides expressed in spermatogenic cells to some extent are processed to their biologically active forms within these cells, and that the majority of this processing occurs when the spermatozoa matures in the epididymis. Thus, biologically active, fully processed CCK and gastrin peptides appear to be important in the distal parts of the genital tract. The possibility that the proCCK and progastrin peptides have a biological function locally in the testis can, however, not be excluded.

The antiserum used in this study for immunohistochemical staining of sections from human testis recognizes the pentapeptide Gly-Trp-Met-Asp-Phe- $\mathrm{NH}_{2}$ common to both CCK and gastrin. The observed immunoreactivity can, therefore, represent either CCK or gastrin or both. Reactivity against a yet unidentified peptide containing this pentapeptide sequence can also not be excluded. However, based on the biochemical characterization of gastrin peptides in extracts of human testis, it appears most likely that the immunoreactivity seen represents progastrin peptides or possibly also processed $\alpha$-carboxyamidated gastrin 17 or gastrin 34. As seen for the CCK-like immunoreactivity in mouse, rat, and monkey testis (22-24), the gastrinlike immunoreactivity in the human testis was localized to the central parts of the seminiferous tubules, where spermatids and spermatozoa are present. In addition, ejaculated spermatozoa were stained in the anterior part, suggesting an acrosomal localization. The results of the subcellular localization by immunoelectron microscopy showed gastrinlike immunoreactivity in the acrosome of human spermatids. A similar analysis of monkey spermatids demonstrated CCK-like immunoreactivity in the acrosome (23). The fact that both immunoreactivities were localized to the acrosome in monkeys and in humans, respectively, suggests that the two peptides have simifar function(s) in the male reproductive system. This is further supported by the fact that the biologically active site in CCK and gastrin resides in their carboxyl-terminal region, i.e., the region which is structurally identical for both peptides.

The acrosome contains enzymes of lysosomal nature which are released during the acrosome reaction, thereby facilitating sperm activation of the egg (39). As discussed earlier $(22,23)$, an interesting possibility is that CCK, or gastrin peptides in humans, are released during the acrosome reaction to interact with receptors on the follicular cells or on the egg cell membrane, thereby activating the egg for fertilization. In support of this hypothesis, Moriarty et al. (25) recently demonstrated the presence of functional CCK receptors on Xenophus Laevis oocyte cell membranes. Furthermore, Kline et al. (40) recently suggested that there may be an endogenous receptor in the egg membrane that is activated by sperm to initiate 
fertilization, and they showed that the serotonin or M1 muscarinic acetylcholine receptors could mimic the putative endogenous receptor. Our finding of CCK or gastrin peptides in the acrosome of spermatids or spermatozoa suggests that these peptides may be components that activate the egg for fertilization, provided that functional receptors can be demonstrated also on mammalian oocytes. Validation of this hypothesis may come from experiments studying the effect of CCK and gastrin agonists or antagonists on fertilization. In addition, the presence of gastrin peptides in human spermatozoa opens possibilities to study their effects on in vitro fertilization in humans.

\section{Acknowledgments}

We thank Dr. A. Horii, Institute for Molecular and Cellular Biology, Osaka University for the human CCK genomic clone; Dr. P. Frey, Sandoz Research Institute, Bern, Switzerland, and Dr. J. Walsh, Center for Ulcer Research and Education, CURE, Los Angeles, CA, for generous supply of rabbit polyclonal CCK antiserum and monoclonal CCK antibodies, respectively; and Dr. V. Mutt, Department of Biochemistry, Karolinska Institutet, Stockholm, Sweden, for donating porcine CCK-33. We also thank Pharmacia, Uppsala, (Dr. H. Björklund and Dr. A. Härfstrand) for supplying monkey tissue and Ms. B. M. Larsson, Department of Surgery, Karolinska Hospital, Stockholm, for preparation of human tissue. The support of Professor $L$. Andersson, Department of Urology, Professor Marc Bygdeman, Department of Obstetrics and Gynecology, and Professor B. Hamberger, Department of Surgery, Karolinska Hospital is greatfully acknowledged.

This study was supported by grants from the National Institute of Mental Health (MH-43230), Swedish MRC (04X-2887), the Royal Swedish Academy of Sciences, the Wenner Gren Foundation, the Swedish Society of Medicine, Fernströms stiftelse, Skandigen AB, Kabigen AB, Swedish NRC, Petrus and Augusta Hedlunds Stiftelse, Emil Aaltonen Foundation, the Danish MRC, and the Danish Biotechnology Program for Neuropeptide Research.

\section{References}

1. Gregory, H., P. M. Hardy, D. S. Jones, G. W. Kenner, and R. C. Sheppard. 1964. The antral hormone gastrin: structure of gastrin. $\mathrm{Na}$ ture. (Lond.). 204:931-933.

2. Jorpes, E., and V. Mutt. 1966. Cholecystokinin and pancreozymin: one single hormone? Acta Physiol. Scand. 66:196-212.

3. Larsson, L.-I., and J. F. Rehfeld. 1977. Evidence for a common evolutionary origin of gastrin and cholecystokinin. Nature (Lond.). 269:335-338.

4. Yoo, J., T. Powell, and K. Agarwal. 1982. Molecular cloning and nucleotide sequence of full length cDNA coding for porcine gastrin. Proc. Natl. Acad. Sci. USA. 79:1049-1053.

5. Boel, E., J. Vuust, F. Norris, K. Norris, A. Wind, J. F. Rehfeld, and K. A. Marcker. 1983. Molecular cloning of human gastrin cDNA: evidence for evolution of gastrin by gene duplication. Proc. Natl. Acad. Sci. USA. 80:2866-2869.

6. Deschenes, R. J., L. J. Lorenz, R. S. Haun, B. A. Roos, K. J. Collier, and J. E. Dixon. 1984. Cloning and sequence analysis of a cDNA encoding rat preprocholecystokinin. Proc. Natl. Acad. Sci. USA. 81:726-730.

7. Deschenes, R. J., S. V. L. Narayana, P. Argos, and J. E. Dixon. 1985. Primary structural comparison of the preprohormones cholecystokinin and gastrin. FEBS (Fed. Eur. Biochem. Soc.) Lett. 182:135-138

8. Takahashi, Y., K. Kato, Y. Hayashizaki, T. Wakabayashi, E. Ohtsuka, S. Matsuki, M. Ikehara, and K. Matsubara. 1985. Molecular cloning of the human cholecystokinin gene by use of a synthetic probe containing deoxyinosine. Proc. Natl. Acad. Sci. USA. 82:1931-1935.
9. Fuller, P. J., D. L. Stone, and S. J. Brand. 1987. Molecular cloning and sequencing of a rat preprogastrin complementary deoxyribonucleic acid. Mol. Endocrinol. 1:306-311.

10. Johnsen, A. H., and J. F. Rehfeld. 1989. Cionin: a dityrosylsulfated hybrid of cholecystokinin and gastrin from the neural ganglion of the protochordate ciona intestinalis. J. Biol. Chem. 265:3054-3058.

11. Rehfeld, J. F. 1981. Four basic characteristics of the gastrincholecystokinin system. Am. J. Physiol. 240:G255-266.

12. Larsson, L.-I., J. F. Rehfeld, F. Sundler, and R. Håkanson. 1976. Pancreatic gastrin in foetal and neonatal rats. Nature (Lond.). 262:609-610.

13. Uvnäs-Wallensten, K., J. F. Rehfeld, L.-I. Larsson, and B. Uvnäs. 1977. Heptadecapeptide gastrin in the vagal nerve. Proc. Natl. Acad. Sci. USA. 74:5707-5710.

14. Rehfeld, J. F. 1978. Localisation of gastrins to neuro- and adeno-hypophysis. Nature (Lond.). 271:771-773.

15. Rehfeld, J. F., L. Bardram, and L. Hilsted. 1989. Gastrin in human bronchogenic carcinomas: constant expression but variable processing of progastrin. Cancer Res. 49:2840-2843.

16. Dockray, G. J. 1976. Immunochemical evidence of cholecystokinin-like peptides in brain. Nature (Lond.). 254:568-570.

17. Rehfeld, J. F. 1978. Immunochemical studies of cholecystokinin. II. Distribution and molecular heterogeneity in the central nervous system and the small intestine of man and hog. J. Biol. Chem. 253:4022-4030.

18. Frey, P. 1985. Changes in cholecystokinin content in rat brain after subchronic treatment with neuroleptics. Ann. N.Y. Acad. Sci. 448:601-603.

19. Hökfelt, T., M. Herrera-Marschitz, K. Seroogy, G. Ju, W. A. Staines, V. Holets, M. Schalling, U. Ungerstedt, C. Post, J. F. Rehfeld, P. Frey, Z. Fischer, G. Dockray, T. Hamaoka, J. H. Walsh, and M. - Goldstein. 1988. Immunohistochemical studies on cholecystokinin (CCK)-immunoreactive neurons in the rat using sequence specific antisera and with special reference to the caudate nucleus and primary sensory neurons. J. Chem. Neuroanat. 1:11-52.

20. Larsson, L.-I., and J. F. Rehfeld. 1979. Localization and molecular heterogeneity of cholecystokinin in the central and peripheral nervous system. Brain Res. 165:201-218.

21. Rehfeld, J. F. 1987. Preprocholecystokinin processing in the normal human anterior pituitary. Proc. Natl. Acad. Sci. USA. 84:3019-3024.

22. Persson, H., A. Ericsson, M. Schalling, J. F. Rehfeld, and T. Hökfelt. 1988. Detection of cholecystokinin in spermatogenic cells. Acta Physiol. Scand. 134:565-566.

23. Persson, H., J. F. Rehfeld, A. Ericsson, M. Schalling, M. PeltoHuikko, and T. Hökfelt. 1989. Transient expression of the cholecystokinin gene in male germ cells and accumulation of the peptide in the acrosomal granule: possible role of cholecystokinin in fertilization. Proc. Natl. Acad. Sci. USA. 86:6166-6170.

24. Pelto-Huikko, M., H. Persson, M. Schalling, and T. Hökfelt. 1989. Immunocytochemical demonstration of cholecystokinin-like immunoreactivity in spermatozoa in epididymis. Acta Physiol. Scand. 137:465-466.

25. Moriarty, T. M., B. Gillo, S. Sealfon, and E. M. Landau. 1988. Activation of ionic currents in Xenopus oocytes by corticotropin releasing peptides. Mol. Brain Res. 4:201-205.

26. Ernfors, P., F. Hallböök, T. Ebendal, M. J. Radeke, T. P. Misko, E. M. Shooter, and H. Persson. 1988. Developmental and regional expression of $\beta$-nerve growth factor receptor messenger RNA in the chick and rat. Neuron. 1:983-996.

27. Aviv, H., and P. Leader. 1972. Purification of biologically active globin messenger RNA by chromatography on oligothymidylic acid cellulose. Proc. Natl. Acad. Sci. USA. 69:1408-1421.

28. Zamboni, L., and S. De Martino. 1967. Buffered picric acid formaldehyde: a new rapid fixative for electron microscopy. J. Cell Biol. 48A:35. (Abstr.)

29. Schalling, M., Ä. Dagerlind, S. Brené, H. Hallman, M. Djur- 
feldt, H. Persson, L. Terenius, M. Goldstein, D. Schlesinger, and T. Hökfelt. 1988. Coexistence and gene expression of phenylethanolamine $N$-methyltransferase, tyrosine hydroxylase and neuropeptide tyrosine in rat and bovine adrenal gland effects of reserpine. Proc. Natl. Acad. Sci. USA. 85:8306-8310.

30. Grima, B., A. Lamouroux, C. Boni, J.-F. Julien, F. Javoy-Agid, and J. Mallet. 1987. A single human gene encoding multiple tyrosine hydroxylases with different predicted functional characteristics. $\mathrm{Na}$ ture (Lond.). 326:707-711.

31. Hilsted, L., and J. F. Rehfeld. 1986. Measurement of precursors for alpha-amidated hormones by radioimmunoassay of glycine-extended peptides after trypsin-carboxypeptidase B cleavage. Anal. Biochem. 152:119-126.

32. Coons, A. N. 1958. Fluorescent antibody methods. In General Cytochemical Methods. J. F. Danielli, editor. Academic Press, New York, 339-422.

33. Berod, A., B. K. Hartman, and J. F. Pujol. 1981. Importance of fixation in immunohistochemistry: use of formaldehyde solutions at variable $\mathrm{pH}$ for the localization of tyrosine hydroxylase. $J$ Histochem. Cytochem. 29:841-850.

34. Frey, P. 1983. Cholecystokinin octapeptide (CCK 26-33), nonsulfated octapeptide and tetrapeptide (CCK 30-33) in rat brain: analy- sis by high pressure liquid chromatography (HPLC) and radioimmunoassay (RIA). Neurochem. Int. 5:811-815.

35. Johnson, D. G., and G. M. de C. Nogueira Araujo. 1981. A simple method of reducing the fading of immunofluorescence during microscopy. J. Immunol. Methods. 43:349-350.

36. Platt, J. L., and A. F. Michael. 1983. Retardation of fading and enhancement of intensity of immunofluorescence by p-phenyl-enediamine. J. Histochem. Cytochem. 31:840-842.

37. Pickel, V. M. 1981. Immunocytochemical methods. In Neuroanatomic Tract Tracing Methods. L. Heimer and M. J. Robards, editors. Plenum Press, New York. 483-509.

38. Sternberger, L. A., P. H. Hardy Jr., J. J. Cuculis, and H. G. Meyer. 1970. The unlabeled antibody enzyme method of immunohistochemistry; preparation and properties of soluble antigen-antibody complex (horseradish peroxidase-antiperoxidase) and its use in identification of spirochets. J. Histochem. Cytochem. 18:316-333.

39. Wasserman, P. 1987. The biology and chemistry of fertilization. Science (Wash. DC). 245:553-560.

40. Kline, D., L. Simoncini, G. Mandel, R. A. Maue, R. T. Kado, and L. A. Jaffe. 1988. Fertilization events induced by neurotransmitters after injection of mRNA in Xenopus eggs. Science (Wash. DC). 241:464-467. 